\title{
ГУМАНИТАРНЫЕ ИССЛЕДОВАНИЯ
}

УдК 371.2

DOI: 10.23951/1609-624X-2017-8-126-130

\section{РОЛЬ ТАТАР В РАЗВИТИИ ПРОСВЕЩЕНИЯ НАРОДОВ ТУРКЕСТАНА И КАЗАХСКИХ СТЕПЕЙ (КОНЕЦ XIX - НАЧАЛО ХХ в.)}

\section{Л. Р. Муртазина}

\section{Институт истории им. Ш. Марджани Академии наук Республики Татарстан, Казань}

\begin{abstract}
Освещается вклад татар в развитие просвещения народов Туркестана и казахских степей, который выражался в создании учебных заведений для татар, в том числе джадидских медресе, в которых обучались и представители других народов, преподавании в русско-туземных школах, организации школ для местных народов. Описывается вклад татарских педагогов в развитие просвещения тюркоязычных народов, а именно в создание учебных пособий и подготовка педагогических кадров для национальных школ.
\end{abstract}

\footnotetext{
Ключевые слова: татарские педагоги, Туркестан, просвещение, обучение, медресе, русско-туземная школа, джадидизм, учебники.
}

Общеизвестно, что татары сыграли большую роль в распространении грамотности среди тюркских народов Туркестана. Несомненно и то, что медресе Бухары, которая славилась как центр богословского образования, сыграли огромную роль в получении образования татарами. Именно их выпускники, следуя традициям учебных заведений Бухары и Хивы, создали в Волго-Уральском регионе знаменитые медресе, основанные на обучении исламской теологии. Однако этот аспект проблемы в пределах данной статьи не будет рассматриваться. Целью настоящей работы является определение роли татар в просвещении народов Туркестана в конце XIX - начале XX в.

Следует отметить, что достижения татарского народа в области духовной культуры других народов до революции, прежде всего в сфере просвещения, долгие десятилетия игнорировались. Вплоть до 90-х гг. ХХ в. основной акцент делался на роль советской власти и компартии СССР. $\mathrm{B}$ процессе изучения антологий педагогической мысли народов СССР ни один факт, подтверждающий роль татарского народа в просвещении народов Туркестана, не был выявлен [1, с. 212]. Однако в работах некоторых исследователей, особенно в первые годы советской власти, например В. В. Бартольда, прослеживаются некоторые моменты, подчеркивающие участие татар в деле просвещения тюркских народов [2]. Не так давно начали появляться работы, в которых рассматриваются аспекты этой проблемы [3-5].

Как известно, в туркестанском крае татары появились сравнительно давно. Многие бежали сюда от насильственной христианизации - это была первая волна татар-переселенцев. Вторая волна наблюдалась во время правления Екатерины II - она привлекала татар к «окультуриванию» кочевников $[6$, c. 32].

Татары, благодаря генеалогическому сходству их языка с другими тюркскими языками, очень легко ими овладевали. Единая религия также имела немаловажную роль. Знание же русского языка позволяло татарам работать в качестве дипломатов, переводчиков от российского правительства, а также посредниками в торговых делах. К концу XIX в. татары составляли довольно значительную часть населения Семипалатинска, Уральска, Петропавловска и других городов.

Татары распространяли мусульманские обычаи и традиции, вносили в степь мусульманскую культуру. Именно поэтому генерал-губернатор Туркестана К. П. фон Кауфман отрицательно относился к духовенству из татар, видя в них в первую очередь степных миссионеров [2, с. 136].

Ученые выяснили, что до присоединения территории Казахстана к России грамотность у казахов была распространена исключительно на татарском языке [6, с. 41]. Даже в казахской школе, которая была организована казахским педагогом И. Алтынсариным при поддержке Н. И. Ильминского, многие учителя были татарами [6, с. 43].

С началом распространения в Туркестане реформаторского движения «джадидизм», появившегося под влиянием и руководством татар, русскотуземные школы, которые функционировали в крае начиная с 80-х гг. XIX в., начали испытывать неко- 
торую конкуренцию с их стороны, так как в плане ознакомления мусульман с европейскими приемами учения эти два вида школ были схожи. Так, открытая в Ташкенте в 1873 г. татарская школа, которая с 1895 г. перешла на преподавание по новому методу, постепенно приобретала и по форме, и по содержанию европейский вид, на уроках уделялось внимание практическому усвоению русского языка [2, c. 130$]$.

К тому же в некоторых местах с компактным проживанием татар где, соответственно, было больше их влияние, русско-туземные школы оказались не совсем конкурентоспособными, так как многие жители предпочитали домашнее обучение с преподавателями-татарами. Так, в волостях, расположенных ближе к городу Петропавловску, к 1913 г. была открыта лишь одна русско-киргизская школа, и она страдала недостаточным количеством учеников - большинство отдавало детей на обучение татарам. Бывали случаи, когда родители из соседних деревень отвозили детей в г. Петропавловск и отдавали в татарские мектебы [7, с. 96].

Не доверяло население и русским училищам, куда доступ был открыт священнику и закрыт мулле. Поэтому признавая традиции мусульманской системы образования, которая подразумевала обучение шариату в школе, при организации русскотуземных школ сочли необходимым, чтобы «в ней преподавался туземцам закон их веры их же муллой» [2, с. 130]. Но это условие не всегда учитывалось, так как не хватало необходимых кадров. Только татарское медресе и в этом плане полностью удовлетворяло потребности мусульман.

Что касается времени возникновения джадидских школ в Туркестане, Н. Бобровников придерживается мнения о том, что они возникли в 19051906 гг. [8, с. 80]. В. Бартольд же считает, что новометодные школы в Туркестане, а именно в Ферганской области, начали появляться уже в конце 1899 1898 гг. [2, с. 136]. Многие факты говорят в пользу второго мнения.

Татарские школы организовывались в первую очередь в городах и имели огромный успех у населения. Их количество по сравнению с русско-туземными школами также было больше. Например, в 1910 г. в Ташкенте было 8 русско-туземных школ, когда как новометодных школ было в два раза больше [2, с. 137]. К 1910 г. в Коканде таких (т. е. джадидских) школ было 16, в Ташкенте - 20, существовали татарские школы и в других местах вплоть до Кульджи [9]. Общее количество новометодных школ в Туркестане к 1910 г. возросло до 89 $[10$, с. 96$]$.

Развитие женского образования в Туркестане также связано с деятельностью татарских педагогов. Эта проблема была рассмотрена в работах ис- следователей Т. А. Биктимировой и Д. Насрутдиновой $[3,10]$.

Татары не только открывали и преподавали в медресе, но и содержали их. Так, в школе для девочек в г. Верном, попечителем которой был 3. Тазетдинов из Вятской губернии, преподавали татарские девушки, окончившие уфимские медресе, М. Якупова и М. Сагдиева, а материальная поддержка осуществлялась татарским купцом Х. Габдульвалиевым и его сыновьями [10, с. 97]. В женской новометодной школе г. Пишпек в 1912-1914 гг. учились 70 девушек (50 из них были татарки и $20-$ кыргызки). Их учили татарки, получившее образование в Казани и Уфе. Обучение велось в основном по той же программе, что в мужской школе, дополнительным предметом было рукоделие [11, c. 44]. Татарки участвовали и в деятельности русско-туземных школ, которые были организованы для местных женщин начиная с 1903 г. [3, с. 3].

Деятельность татарских просветительниц в Туркестане важна не только тем, что они проложили дорогу женскому образованию, но и тем, что содействовали организации подготовки педагогических кадров из среды местного населения и организации национальных школ. Под влиянием татарок в 1913 г. М. Холикий открыл женскую новометодную школу в г. Коканд, где преподавала и его сестра Салияхон дочь Абдулхалика [3, с. 16].

Однако правительство боялось усиления влияния поволжских татар в Туркестане, видя в них распространителей пантюркистских и панисламистских идей, поэтому старалось всячески противодействовать их деятельности. В 1910 г. было создано «Особое совещание для выработки мер по противодействию татаро-мусульманскому влиянию». Одной из первых мер на пути реализации этого плана явилось распоряжение туркестанской администрации о запрещении преподавательской деятельности татар в школах Туркестана. Газета «Тарджиман» от 20 апреля 1912 года, ссылаясь на газету «Вакыт», пишет, что туркестанская администрация издала распоряжение о том, что «в новометодных и старометодных мектебах учителями могут быть лица, принадлежащие к роду и племени учеников. Сарт не может обучать киргизов, татарин - сартов» [12]. Эти правила должны были войти с 1 июля, и мектебы, не соответствующие им, должны были закрываться. Но, как указывает Н. Бобровников, «учителя сарты были менее подготовлены, и часто, по отзывам местных учителей, они только механически копировали учителей-татар, но, с другой стороны, эта мера вызвала издание учебников на сартовском языке, что должно иметь огромное значение» [7, с. 80].

Данная проблема была освещена в периодической печати того времени. Например, газета «Йол- 
дыз» проявила озабоченность тем, что «мектебы, открытые татарами в Туркестанском крае, закрываются, когда как школы, где преподавателем состоит сарт, продолжают работать» [13]. В журнале «Инородческое обозрение» за март 1913 г. приводится мнение по этому поводу заместителя Министра внутренних дел А. Н. Харузина, опасавшегося влияния тюркских народностей друг на друга, который поэтому был против назначения татар в киргизские школы [14, с. 132].

Однако татарские просветители, хотя и отрицательно относились к этим правилам, были уверены, что они останутся на только бумаге, потому что в Туркестане к тому периоду не было ни одного инспектора народных училищ, который бы владел местными языками и мусульманской письменностью, чтобы соответствующим образом оценивать преподавание в мусульманских школах [7, c. 62]. Они также были уверены в том, что с закрытием татарских школ новометодное обучение не перестанет существовать, так как и среди сартов начали появляться учителя, кто мог бы преподавать на основе нового метода [13]. Поэтому татарские школы продолжали работать и после выхода правил, обучались в них, кроме самих татар, представители других национальностей Туркестана. Так, в школе для девочек в Верном в 1913 г. вместе с татарками получали образование еще 9 киргизок и 9 узбечек [10, с. 97].

В новометодных школах, где обучались дети разных национальностей, а именно татар, узбеков, дунган, кашгарцев и киргизов, преподавали на основе учебников татарских авторов - букварей Х. Максудова «Мөгаллим әүвәл» («Первый учитель»), «Мөгаллим сани яки әлифба гарәби» («Второй учитель, или Арабская азбука»), хрестоматиям Р. Фахретдинова «Тәрбияле бала» («Воспитанный ребенок»), Х. Забирова «Рәһбәре сыйбиян» («Путеводитель для детей»). Изучение религиозных обязанностей проводилось по учебнику Х. Максудова «Гыйбадәте исламия» («Введение в практику ислама») [7, с. 46-51]. Татарский был языком обучения и документации. В школе, которая была открыта в 1902 г. в Пишпеке при татарской мечети, обучение на всех отделениях велось на татарском языке [15, с. 40-41]. Известно также, что окончившим курс медресе «Экбаль» выдавали дипломы на татарском языке [16, с. 21]. Здесь готовили учителей и учащихся для поступления в медресе Казани и Уфы [16, с. 22].

Еще одна проблема заключалась в обеспечении школ Туркестана учебниками на местных языках. И в этом отношении роль татарских педагогов и казанских типографий несомненна. В начале ХХ в. в Казани были изданы десятки литературных и просветительских трудов, которые послужили формированию литературного языка, грамотности среди народов Туркестана [16, с. 17]. Первые стихи Абая, который получил образование у татарского муллы, затем в одном из татарских медресе Семипалатинска, были опубликованы в оренбургских татарских изданиях. Учебники для казахских детей просветителя И. Алтынсарина также были напечатаны в Казани.

В конце XIX - начале XX в. в Казани велось активное издательство учебников для народов Туркестана. Например, в 1859 г. в типографии Казанского университета по заказу оренбургского генералгубернатора было напечатано пособие «Начальное руководство к изучению арабского, персидского и татарского языков с кратким объяснением существующих в Оренбургском крае наречий башкир и киргизов с приложением к нему русско-персидскотатарских слов, разговоров и прописей» М. Бикчурина. В подготовке учебников для этих школ участвовал и татарский педагог, преподаватель медресе «Галия» и «Хусаиния» Г. Шнаси. Его учебные пособия по химии, физике и методике обучения отдельным предметам, переработанные с адаптацией для данных категорий и переведенные на казахский, узбекский, таджикский, башкирский языки, в течение десятилетий использовались в просвещении разных национальностей России вплоть до конца 20-х гг. [17, с. 122, 123]. При этом татарские просветители, активно участвовавшие в подготовке учебников и издании газет на языках других тюркских народов, выдвигали лишь одно условие - «не отчуждаться от прочих тюрков и знать татарский язык» [7, с. 70].

В подготовке педагогических кадров для школ Туркестана огромную роль играли татарские медресе Поволжского региона. С началом массового изгнания татарских мугаллимов из Туркестана, в ответ на требования о принадлежности учителя к конкретной племенной группе, «Галия» резко увеличила прием шакирдов нетатар (казахов, туркмен, черкесов и т. д.). С 1906 по 1916 г. в медресе учились 242 посланца из Средней Азии [16, с. 17].

Знаменитое Стерлибашевское медресе также было одним из центров образования для тюркских. В медресе вместе с другими обязательными языками, такими как персидский и арабский, преподавались татарский и казахский языки. Некоторые особо способные ученики оставлялись в медресе для обучения казахских детей. Татарский просветитель М. Акмулла (1831-1895), который учился и преподавал в Стерлибашевском медресе, в 25-летнем возрасте уехал в казахские степи, обучал казахских детей. Хорошо знавший творчество казахских акынов, он и сам сочинял стихи на казахском языке. Псевдоним Акмулла ему был дан казахами после того, как умер их известный поэт с таким же име- 
нем [18, с. 406, 411]. Многие тюркские народы татары, башкиры, казахи, киргизы, ногайцы - считали Акмуллу своим поэтом.

Таким образом, во второй половине XIX - начале XX в. татарские просветители сыграли заметную роль в просвещении народов Туркестана. Их деятельность, направленная на заложение основ светского образования посредством новометодных школ, подготовку педагогических кадров и учебнометодических изданий на этих языках, содействовала созданию системы национального образования народов Туркестана.

\section{Список литературы}

1. Murtazina L. R. The Theoretic and Methodological Foundation of Studying Tatar Pedagogical Thought (On the Experiment of compiling an Antology of Tatar Pedagogical Thought) // TATARICA. 2014. № 1 (2). P. 209-222.

2. Бартольд В. В. История культурной жизни Туркестана. 1927. 256 с.

3. Насретдинова Д. М. Туркистоннинг маданий хаётида татар-бошқирд аёлларининг тутган ўрни (XIX аср охири - XX асрнинг биринчи чораги): тарих ф. дис. автореф. Тошкент, 2011. 29 б.

4. Расулов А. Н. История взаимоотношений народов Туркестана, Поволжья и Приуралья (1917-1924): автореф. дис. ... д-ра ист. наук. Ташкент, 2005. 54 с.

5. Татар педагогик фикере антологиясе. 2 томда. Том 1 / ред. Ф. М. Солтанов, М. М. Гибатдинов, Л. Р. Мортазина. Казан, 2012.407 б.

6. Хафиизов Г. Г. Культуртрегерская деятельность татарской интеллигенции в XIX - первой четверти XX в. Казань, 2003. 283 с.

7. Приходов М. Киргизы-мусульмане // Инородческое обозрение. Приложение к журналу “Православный собеседник”, март 1913 года. Кн. 2. Казань: Центр. тип., 1913. С. 83-112. Б

8. Бобровников Н. А. Русско-туземные училища, мектебы и медресы Средней Азии: путевые заметки. СПб.: Сенатская тип., 1913. 90 с.

9. Тарджиман. 1910. 15 октября.

10. Биктимирова Т. Ил язмышын салып иңнәренә. Казан: Алма-Лит, 2006. 239 б.

11. Иманкулов М. К. Развитие системы образования в начале XX века // Известия Кыргызской академии образования. 2016. № 1 (37). C. $42-46$.

12. Тарджиман. 1912. 20 апреля.

13. Ысулы жәдидә // Йолдыз. 1911. 11 января.

14. Русские мусульмане // Инородческое обозрение. Приложение к журналу “Православный собеседник", март 1913 года. Кн. 2. Казань: Центр. тип., 1913. С. 131-133.

15. Айтмамбетов Д. Дореволюционные школы в Киргизии. Фрунзе: Изд-во АН Киргизской ССР, 1961. 128 с.

16. Галимова А. Р. Литературные связи киргизской и татарской поэзии конца XIX - первой половины XX в. Бишкек: Изд-во КРСУ, 2015. $142 \mathrm{c}$.

17. Муртазина Л. Р. Научно-педагогическая деятельность Габдуллы Сабировича Шнаси (1885-1938) // Вестник Томского гос. пед. ун-та (TSPU Bulletin). 2016. № 8. C. 121-124.

18. Фәхреддин Р. Асар. 3 hәм 4 томнар. Казан: Рухият, 2010. 648 б.

Муртазина Ляля Раисовна, кандидат педагогических наук, ведущий научный сотрудник, Институт истории им. Ш. Марджани Академии наук Республики Татарстан (ул. Батурина, 7, Казань, Республика Татарстан, Россия, 420111). E-mail: lyalyamur@mail.ru

Материал поступил в редакциию 03.04.2017.

DOI: 10.23951/1609-624X-2017-8-126-130

\section{THE ROLE OF TATARS IN DEVELOPMENT OF EDUCATION OF THE PEOPLE OF TURKESTAN AND KAZAKH STEPPE (THE END OF XIX - BEGINNING OF XX CENTURIES)}

\section{R. Murtazina}

Academy of Sciences of the Republic of Tatarstan, Kazan, Russian Federation

The article presents activities of the Tatars in the development of the education of the people of Turkestan. First of all it was expressed in creation of schools for Tatars, including the Jadid's madrassas, attended by representatives of other peoples. Training was on the books of the Tatar authors - S. Maksudi, R. Fakhrutdinov, H.Zabirov. National schools for the local people were organized under the leadership of the Tatar enlighteners. They participated in preparation of textbooks in the languages of the local people and teaching staff for national schools. The Tatars spreaded Muslim customs and traditions, brought Muslim culture in the steppe. Jadid's schools opened by tatars have sustained the competition from Russian-native schools because local population trust them more which was connected by a religion community, similarity of language and traditions of Tatars and people of Turkestan. These schools 
financially were also supported by Tatars. Methodical providing, especially in the first decades of their existence, was carried out by the Kazan teachers. Most capable shakirds (students) of Jadid's madrassas prepared to enter major madrasas of the Volga-Ural region. Tatar women played a big role in training of women of Turkestan. Under their influence and leadership by the representatives of the local population were opened schools. However, despite the support for the first time, the government feared the influence of the Turkic peoples on each other. Since 1910, rules have been adopted that prohibit the teaching of Tatars in Turkestan. Closing of Tatar schools did not become an obstacle to the spread of jadidism.

Key words: Tatar teachers, Turkestan, education, training, madrasa, Russian-native school, Jadidism, textbooks.

\section{References}

1. Murtazina L. R. The Theoretic and Methodological Foundation of Studying Tatar Pedagogical Thought (On the Experiment of compiling an Antology of Tatar Pedagogical Thought). TATARICA, 2014, no. 1 (2), pp. 209-222.

2. Bartol'd V. V. Istoriya kul'turnoy zhizni Turkestana [History of cultural life of Turkestan]. 1927, 256 p. (in Russian).

3. Nasretdinova D. M. Turkistonning madaniy xaetida tatar-boshķird aellarining tutgan y $r$ rni (XIX asr okhiri - XX asrning birinchi choragi). Tarikh $\mathrm{f}$. diss.avtoref. [The role of Tatar-Bashkir women in cultural life of Turkistan (the end of the 19th - the first quarter of the 20th centuries]. Toshkent, 2011. 29 p. (in Uzbek).

4. Rasulov A. N. Istoriya vzaimootnosheniy narodov Turkestana, Povolzh'ya i Priural'ya (1917-1924). Avtoref. dis. dokt. ist. nauk [History of Relationship Between Peoples of Turkestan, the Volga region and the Ural provinces (1917-1924). Abstract of thesis doct. hist. sci.]. Tashkent, 2005. 54 p. (in Russian).

5. Tatar pedagogik fikere antologiyase. 2 tomda. T. 1. Red. F. M. Soltanov, M. M. Gibatdinov, L. R. Mortazina [Antology of Tatar pedagogical thought. In 2 volumes. Vol. 1. Ed. by F. M. Soltanov, M. M. Gibatdinov, L. R. Mortazina]. Kazan, 2014. 407 p. (in Tatar).

6. Khafizov G. G. Kul'turtregerskaya deyatel'nost' tatarskoy intelligentsiy $v$ XIX - pervoy chetverti XX v. [Kulturtregerskih activities of the Tatar intelligences in the XIX - first quarter XX centuries]. Kazan, 2003. 283 p. (in Russian).

7. Prikhodov M. Kirgizy-musul'mane [Muslim Kirghiz]. Inorodcheskoye obozreniye. Prilozheniye k zhurnalu "Pravoslavnyy sobesednik" za mart 1913 goda. Kn. 2 [Foreign review. Supplement to the magazine «Orthodox interlocutor», March 1913. Book 2]. Kazan, Tsentr. Tip. Publ., 1913. pp. 83-112 (in Russian).

8. Bobrovnikov N. A. Russko-tuzemnye uchilishcha, mekteby i medresy Sredney Azii: putevye zametki [Russian-native schools, mektebas and madrassas of Central Asia: traveling notes]. Saint Petersburg, Senatskaya tip. Publ., 1913. 90 p. (in Russian).

9. Tardzhiman. 1910. 15 oktyabrya (in Russian).

10. Biktimirova T. Il yazmyshyn salyp innärenä [The fate of the country on brittle shoulders]. Kazan, Alma-Lit Publ., 2006. 239 p. (in Tatar).

11. Imankulov M. K. Razvitiye sistemy obrazovaniya v nachale XX veka [The development of the education system in the early twentieth century]. Izvestiya Kyrgyzskoy akademii obrazovaniya - Proceedings of the Kyrgyz Academy of Education, 2016, no. 1 (37), pp. $42-46$ (in Russian).

12. Tardzhiman. 1912. 20 aprelya (in Russian).

13. Ysuly cädidä [Dzhadid method]. Yoldyz. 1911. 11 yanvar. (in Tatar)

14. Russkiye musul'mane [Russian Muslims]. Inorodcheskoye obozreniye. Prilozheniye k zhurnalu "Pravoslavnyy sobesednik" za mart 1913 goda. Kn. 2 [Foreign review. Supplement to the magazine «Orthodox interlocutor», March 1913. Book. 2]. Kazan, Tsentr. Tip. Publ., 1913. pp. 131-133 (in Russian).

15. Aytmambetov D. Dorevolyutsionnye shkoly v Kirgizii [Pre-revolutionary schools in Kyrgyzstan]. Frunze, Izd-vo AN Kirgizskoy SSR Publ., 1961. 128 p. (in Russian).

16. Galimova A. R. Literaturnye svyazi kirgizskoy i tatarskoy poezii kontsa XIX - pervoy poloviny XX v. [Literary relations of the Kirghiz and the Tatar poetry of the end of XIX - first half XX century]. Bishkek, KRSU Publ., 2015. 142 p. (in Russian).

17. Murtazina L. R. Nauchno-pedagogicheskaya deyatel'nost' Gabdully Sabirovicha Shnasi (1885-1938) [Scientific and pedagogical activity of Gadbulla Sabirovich Shnasy (1885-1938)]. Vestnik Tomskogo gosudarstvennogo pedagogicheskogo universiteta - TSPU Bulletin, 2016, no. 8, pp. 121-124 (in Russian).

18. Fäkhreddin R. Asar. 3 häm 4 tomnar. Kazan: Rukhiyat, 2010. 648 p. (in Tatar)

Murtazina L. R., Center of Histori and Theory of the National Education, Sh. Marjani Institute of History, Academy of Sciences of the Republic of Tatarstan (ul. Baturina, 7, Kazan, Respublika Tatarstan, Russian Federation, 420111).

E-mail: lyalyamur@mail.ru 